\title{
НАУКОВО-ПРАКТИЧНА КОНФЕРЕНЦІЯ З МГЖНАРОДНОЮ УЧАСТЮ «АКТУАЛЬНІ ІНФЕКЦІЙНІ ЗАХВОРЮВАННЯ. СУЧАСНІ АСПЕКТИ КЛІНІКИ, ДІАГНОСТИКИ, ЛІКУВАННЯ ТА ПРОФІЛАКТИКИ»
}

\author{
Національний військово-медичний клінічний центр «ГВКГ», м. Київ
}

\begin{abstract}
Наведено коротку інфрормацію про науково-практичну конфреренцію з міжнародною участю «Актуальні інфекційні захворювання. Сучасні аспекти клініки, діагностики, лікування та профрілактики», яка відбулася 23-24 листопада 2017 р. у Національному військово-медичному клінічному чентрі «ГВКГ» у м. Києві.
\end{abstract}

Ключові слова: науково-практична конфреренція, інфекційні захворювання.

23-24 листопада 2017 року у Національному військовомедичному клінічному центрі «ГВКГ», м. Київ, відбулась науково-практична конореренція з міжнародною участю «Актуальні інфекційні захворювання. Сучасні аспекти клініки, діагностики, лікування та профрілактики».

Конференцію організували фрахівці з Української військово-медичної академії, ДУ «Інститут епідеміології та інфекційних хвороб ім. Л.В. Громашевського НАМН України», Національного військово-медичного клінічного центру «ГВКГ» МО України, кафедри дитячих інсрекційних хвороб Національного медичного університету ім. О.О. Богомольця, кафедри інфекційних хвороб Національної медичної академії післядипломної освіти ім. П.Л. Шупика МОЗ України.

Конференцію відкрив Трихліб В.І., Д.мед.н., профресор касредри військової терапії УВМА, полковник м/с запасу (Київ). 3 вітальними словами виступили: Савицький В.Л., д.мед.н., професор, полковник м/с, начальник УВМА, Казмірчук А.П., к.мед.н., генерал-майор м/с, начальник Національного військово-медичного клінічного центру «ГВКГ» МО України, Задорожна В.І., д.мед.н., професор, член-кор. НАМН України, директор ДУ «Інститут епідеміології та інсрекційних хвороб ім. Л.В. Громашевського НАМН України», Крамарьов С.О., Д.мед.н., професор, зав. кафедри дитячих інсекційних хвороб НМУ ім. О.О. Богомольця.

Про стан інфекційної захворюваності в Україні та проблемні питання, які існували в цьому році у військовослужбовців, доповів Трихліб В.І. (Київ).
3 приводу особливостей перебігу, діагностики, лікування захворювань печінки виступили: Осьодло Г.В., д.мед.н., професор, полковник м/с, начальник кафедри військової терапії УВМА; від групи авторів Трихліб В.І. (Київ); Алхазов Ю., лікар-інсрекціоніст медичного центру «EuroMed», член EASL та APASL, полковник м/с запасу (Баку, Азербайджан); Федорченко С.В., д.мед.н., ст.н.с., завідувач науковим відділом вірусних гепатитів та СНІДу, ДУ «Інститут епідеміології та інсрекційних хвороб ім. Л.В. Громашевського НАМН України» (Київ); Динник О.Б., к.мед.н., президент Української асоціації фрахівців УЗД, член групи експертів МОЗу з напрямку «Радіологія», ст.н.с. Інституту фрізіології НАМН України (Київ); Чумак А.А., д.мед.н., професор, директор Інституту клінічної радіології ДУ «Національний науковий центр радіаційної медицини НАМН України» (Київ); Чабан Т.В., д.мед.н., професор, завідувач кафедри інфекційних хвороб Одеського НМУ; від групи авторів Васильєва Н.А., д.мед.н., професор кафредри інфеекційних хвороб з епідеміологією ДВНЗ «Тернопільський державний медичний університет ім. І.Я. Горбачевського МОЗ України»; від групи авторів Шевченко-Макаренко О.П., к.мед.н., доцент кафедри інфрекційних хвороб ДЗ «Дніпропетровська медична академія МОЗ України».

3 приводу різних питань дитячих інфекцій доповіли: Задорожна В.І.; Маричев І.Л., к.мед.н., ст.н.с. ДУ «Інститут епідеміології та інфекційних хвороб ім. Л.В. Громашевського НАМН України» (Київ); від групи авторів Палатна Л.О., к.мед.н., доцент, кафедра дитячих інфекційних хвороб НМУ ім. О.О. Богомольця (Київ); Євтушенко В.В., к.мед.н., доцент кафредри дитячих інфекційних хвороб НМУ ім. О.О. Богомольця (Київ); Голуб А.П., к.мед.н., доцент, кафедра інфекційних хвороб Національної медичної академії післядипломної освіти ім. П.Л. Шупика (Київ).

З приводу особливостей інфузійної терапії та сепсису виступив Черній В.І., д.мед.н., професор, член-кор. НАМН України, головний науковий співробітник наукового відділу малоінвазивної хірургії (Київ). 
3 приводу діарейних інфекцій: від групи авторів Усачова О.В., д.мед.н., профресор, завідувач кафредри дитячих інсрекційних хвороб Запорізького державного медичного університету.

З приводу грипу, клінічних проявів, лікування, імунних зрушень виступили: Крамарьов С.О. (Київ); від групи авторів Малий В.П., д.мед.н., професор, завідувач кафедри інфекційних хвороб Харківської медичної академії післядипломної освіти; Дихановська Т.А., ДЗ «Український центр 3 контролю та моніторингу захворювань МОЗ України», завідувач Центру грипу та ГРВІ (Київ); Ракша-Слюсарева О.А., д.біол.н, професор кафедри медичної біології, мікробіології, вірусології та імунології Донецького НМУ МОЗ України (Краматорськ); Карлова Т.О., завідувач відділення організації епідеміологічних досліджень ДУ «Харківський обласний лабораторний центр МОЗ України»; Бойко В.О., к.мед.н., доцент, кафедра інфекційних хвороб Національної медичної академії післядипломної освіти ім. П.Л. Шупика (Київ).

Про особливості перебігу, клінічні прояви різних герпесвірусних захворювань доповіли: Незгода І.І., д.мед.н., професор, завідувач кафедри дитячих інфекційних хвороб Вінницького НМУ; Руденко А.О., д.мед.н., професор, завідувач відділом нейроінфекцій ДУ «Інститут епідеміології та інфекційних хвороб ім. Л.В. Громашевського НАМН України» (Київ); Горбаль Н.Б., асистент кафредри дитячих інфекційних хвороб ДВНЗ «Івано-Франківський національний медичний університет»; від групи авторів Клименко Х.П. із кафедри дитячих інсекційних хвороб Львівського НМУ ім. Данила Галицького.

3 питань біологічної загрози виступила Виноград Н.О., д.мед.н., професор, завідувач кафредри епідеміології Львівського НМУ ім. Д. Галицького.

3 приводу актуальних питань моніторингу епідеміологічної ситуації паразитозів України від групи авторів виступила Ніколаєнко С.М., к.мед.н., завідувач паразитологічного відділу з лабораторією ДЗ «Український центр з контролю та моніторингу захворювань МОЗ України» (Київ).

Відносно сказу та актуальних проблем у сучасних умовах виступила від групи авторів Шевченко-Макаренко О.П., к.мед.н., доцент кафедри інфекційних хвороб дЗ «Дніпропетровська медична академія МОЗ України».

Про можливості променевої діагностики поранень, ускладненого, неускладненого ранового каналу доповіла від групи авторів Гречаник О.І., підполковник м/с., к.мед.н., начальник відділення УЗД клініки променевої діагностики і терапії НВМКЦ «ГВКГ» (Київ).

Про актуальне питання бореліозу доповіли від групи авторів Небогаткін І.В., к.біол.н., біолог відділу особливо небезпечних інфекцій Дз «Український центр з контролю та моніторингу захворювань МОЗ України» (Київ); Клюс В.Ю., ДУ «Інститут епідеміології та інсрекційних хвороб ім. Л.В. Громашевського НАМН України» (Київ).

3 приводу різних питань туберкульозу доповіли: Швец О.Н., з кафредри Харківського НМУ (про розповсюдженість та результати лікування хіміорезистентного туберкульозу легень серед осіб з вперше встановленим діагнозом); Матвєєва С.Л., к.мед.н., доцент кафедри сртизіатрії та пульмонології Харківського НМУ (про вплив селену на функцію щитоподібної залози та ефективність хіміотерапії у хворих на туберкульоз із супутнім цукровим діабетом та автоімунним тиреоїдитом).

3 різних питань антибактерійної терапії, їх наслідків виступили: від групи авторів Трихліб В.І. (Київ); Дуда О.К., д.мед.н., профессор, завідувач кафредри інсрекційних хвороб Національної медичної академії післядипломної освіти ім. П.Л. Шупика (Київ); Осьодло Г.В. (Київ); від групи авторів Сухов Ю.О., к.мед.н., доцент кафедри інфекційних хвороб Національної медичної академії післядипломної освіти ім. П.Л. Шупика (Київ).

Про новітні технології в діагностиці та лікуванні інфекційних хвороб доповіли: від групи авторів Матяш В.І., д.мед.н., профресор; Говорова Д.В., к.мед.н., відділення інтенсивної терапії і детоксикації ДУ «Інститут епідеміології та інфекційних хвороб ім. Л.В. Громашевського НАМН України» (Київ).

Про застосування озонотерапії в комплексі з загальноприйнятими методами лікування епідемічного паротиту доповів від групи авторів Нагієв А.М., полковник м/с запасу, Медичний центр «Здорова сім'я», Азербайджанський Медичний Університет (Баку, Азербайджан).

Білонік О.І., лікар-бактеріолог лабораторії особливо небезпечних інфекцій Дз «Український центр з контролю та моніторингу захворювань МОЗ України» (Київ), доповіла про моніторинг комунальних і виробничих підприємств на наявність збудника легіонельозу за період 2011-2016 рр.

Також окремо відбулася підсекція магістерських і студентських робіт.

Була прийнята резолюція конфреренції. 


\section{SCIENTIFIC-PRACTICAL CONFERENCE WITH INTERNATIONAL PARTICIPATION «RELEVANT INFECTIOUS DISEASES. MODERN ASPECTS OF THE CLINIC, DIAGNOSIS, TREATMENT AND PREVENTION》}

V.I. Trykhlib

SUMMARY. This article provides information about scientific-practical conference with international participation «Relevant infectious diseases. Modern aspects of the clinic, diagnosis, treatment and prevention» that was held on the 23-24 of November 2017 at the National Military Medical Clinical Center «Chief Military Clinical Hospitalıin Kyiv.

Key words: scientific-practical conference, infectious diseases.

\section{Відомості про автора}

Трихліб Володимир Іванович - д.мед.н., професор кафедри військової терапії Української військово-медичної академії; v.tryhleb@gmail.com

Information about author

Trykhlib V. - MDS, Professor of the Department of Military Therapy of the Ukrainian Military Medical Academy; v.tryhleb@ gmail.com

Конорлікту інтересів немає.

Author has no conflict of interest to declare.

Отримано 4.12.2017 р. 